\title{
Production of transgenic Indica rice (Oryza sativa L.) Cv. MR 81 via particle bombardment system
}

\author{
Zuraida Abdul Rahman ${ }^{1 *}$, Zulkifli Ahmad Seman ${ }^{1}$, Suri Roowi ${ }^{1}$, Naziah \\ Basirun $^{1}$ and Sreeramanan Subramaniam ${ }^{2}$
}

\author{
${ }^{1}$ Biotechnology Research Centre, Malaysian Agricultural Research and Development \\ Institute (MARDI), P.O. Box 12301, GPO, 50774 Kuala Lumpur, Malaysia; ${ }^{2}$ School of \\ Biological Sciences, Universiti Sains Malaysia (USM), Minden Heights, 11800, \\ Georgetown, Penang, Malaysia
}

\begin{abstract}
Embryogenic callus of rice (Oryza sativa L. cv. MR 81 and Taipei 309) were bombarded with the recombinant pRQ6 construct carrying the hygromycin phosphotransferase $(h p h)$ and $\beta$-glucuronidase (gusA) genes using particle bombardment system. Transformed embryogenic callus that are capable of growing on selection media containing $50 \mathrm{mg} / \mathrm{L}$ hygromycin B developed GUS expression based on blue colouration in the presence of 5-bromo4-chloro-3-glucuronic acid. These embryogenic callus consisted of both transformed (blue) and non-transformed (yellow or white cells). The integration of $h p h$ gene into rice genome was confirmed by Southern blot hybridization. Regenerated plantlets were transferred to soil in pots, and grown to maturity under glasshouse conditions. Rice (R1) seedlings derived from R0 transgenic plants germinated normally in a medium containing $50 \mathrm{mg} / \mathrm{L}$ hygromycin $\mathrm{B}$ and also expressed GUS activity as revealed by histochemical assay. The Southern blot analysis further confirmed the insertion of the $h p h$ gene in the rice genome of the R1 plants of MR 81 and Taipei 309. A simple and economic procedure for screening large number of putative resistant rice plants was described.
\end{abstract}

Key words: Rice embryogenic callus, Particle bombardment, gus $A$ gene, $h p h$ gene.

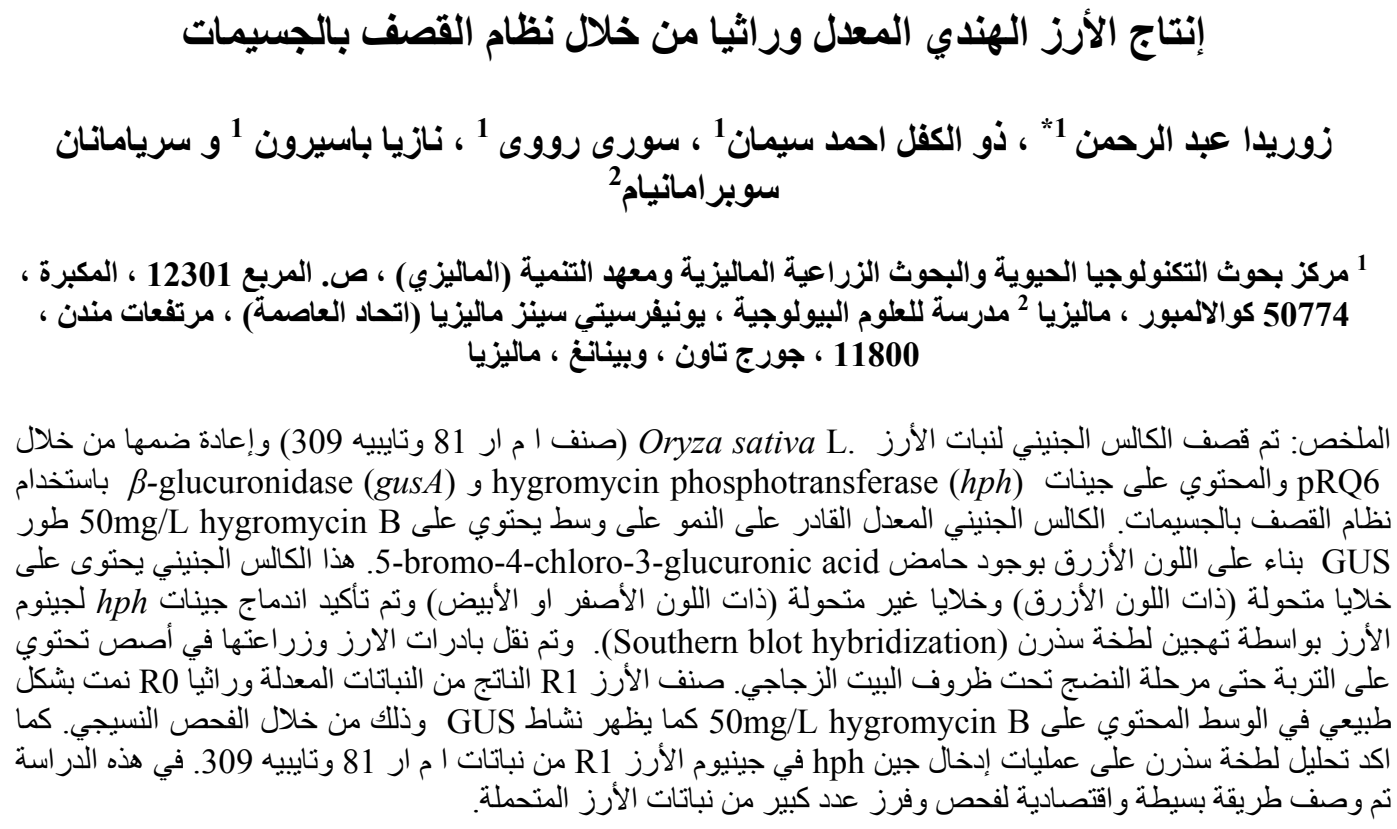

*Corresponding Author, Email: azuraida@mardi.my 


\section{Introduction}

Direct foreign gene transfer into intact tissues by particle bombardment is regarded as the most efficient and consistent genotype-independent approach for gene transfer across japonica and indica rice lines (Christou et al., 1991; Valdez et al., 1998; Srivastava and Ow, 2001; Visarada and Sarma, 2004; Grewal et al., 2006). The bombardment technique has been also used to achieve stable transformation of soybean (McCabe et al., 1999), cotton (Finer and McMullen, 1990), barley (Bregitzer and Tonks, 2003), sugar cane (Bower and Birch, 1992), oats (Somers et al., 1992) and wheat (Weeks et al., 1993; Becker et al., 1994).

Our attempts at rice transformation have been concentrated using this method as the success has been widely reported for various crops and is a routine procedure in many laboratories (Srivastava and Ow, 2001; Visarada and Sarma, 2004; Grewal et al., 2006). The choice of target tissue is one of the major factors for successful transfer of the gene of interest into rice. This target tissue must eventually be able to produce fertile plants from the in vitro culture procedures with some researchers reported that the callus cultures derived from mature seeds or immature seeds have the potential to regenerate high number of fertile rice plants (Sivamani et al., 1996; Chen et al., 1998).

In this study, we were focused on the production of transgenic indica rice plants cv. MR 81 via particle bombardment system and the transmission of both $h p h$ and gusA to its progenies into the first generation (R1). Concurrently, transgenic japonica rice plants $\mathrm{cv}$. Taipei 309 was also obtained as a universal control since the particle bombardment technique have been reported successful to produce fertile transgenic japonica rice plants (Chen et al., 1998). Thus, improvement in the rice production and productivity is achievable when genotypes of specific barriers using genetic engineering systems are overcome.

\section{Materials and Method}

\section{Plant materials and tissue culture}

Mature seeds of rice cv. MR 81 and Taipei 309 were obtained from the MARDI Rice Research Centre in Kepala Batas, Penang. Indica rice, MR 81 was chosen for use in the particle bombardment transformation experiment for it is one of the varieties released by MARDI. The parents of MR 81 are the two varieties, IR 36 and Pankhari. Taipei 309 serves as the control model as a comparison. Rice plants MR 81 and Taipei 309 were grown in the glasshouse at MARDI, Serdang, Malaysia.

\section{Callus induction and regeneration}

Mature seeds were harvested, dehusked and sterilized with $70 \%$ ethanol for $5 \mathrm{~min}$, followed by $20 \%$ sodium hypochloride and washed three times with sterile distilled water. Five seeds were placed onto each Petri dish with callus induction (CI) medium, described below (Table 1), and the plates incubated in the dark at $24^{\circ} \mathrm{C}$. The different medium for Indica rice MR 81 used in these experiments was based on those described by Murashige and Skoog (1962). All the medium namely callus induction (CI), preregeneration medium (PM), callus regeneration (CR) and osmoticum medium (OM) contained the following basic ingredients: MS (Murashige and Skoog, 1962) basal salts, $30 \mathrm{~g} / \mathrm{L}$ sucrose, $1.0 \mathrm{~g} / \mathrm{L}$ thiamine-HCL, $1.0 \mathrm{~g} / \mathrm{L}$ casein hydrolysate, $0.5 \mathrm{~g} / \mathrm{L}$ proline, gelrite, $\mathrm{pH} 5.8$. The $\mathrm{CO}$ medium contained an additional of $0.4 \mathrm{M}$ total carbohydrates, $30 \mathrm{~g} / \mathrm{L}$ sorbitol and mannitol. Optimisation of phytohormone levels, auxin (2,4-dichlophenoxyacetic acid (2,4-D), and cytokinin (6benzylaminopurine) BAP, in CI using medium was carried out previously (Hamidah, unpublished data) to determine the medium formulation for callus induction. To test the callus regeneration ability after selection on hygromycin B containing medium, CI medium was supplied with $20,30,40$, and $50 \mathrm{mg} / \mathrm{L}$ 
hygromycin $\mathrm{B}$, and callus regeneration frequency $(\mathrm{CRF} \%)$ was recorded. The callus induction medium and the procedure to transform and regenerate Taipei 309 seeds are as described by Li et al. (1993).

Table 1. Summary of the comparison of the protocol from callus induction to transformed plants expressing GUS and hygromycin resistance in Taipei 309 (Japonica) and MR81 (Indica).

\begin{tabular}{|c|c|c|}
\hline & Taipei 309 (seeds) & MR 81 (seeds) \\
\hline 1. Callus induction medium & $\begin{array}{l}\text { N6 macro and B5 micro salts, } \\
\text { B5 vitamins, } 2 \mathrm{mg} / \mathrm{L} 2,4-\mathrm{D} \\
\text { (NB medium) }\end{array}$ & $\begin{array}{l}\text { MS macro and micro salts, B5 } \\
\text { vitamins, } 2 \mathrm{mg} / \mathrm{L} 2,4-\mathrm{D} \text { (CI } \\
\text { medium) }\end{array}$ \\
\hline 2. Callus Age & 4 weeks & 4 weeks \\
\hline 3. Pre-bombardment & N6 macro and B5 micro salts, & $\mathrm{MB}+30 \mathrm{mg} / \mathrm{L}$ sorbitol +30 \\
\hline Treatment & $\begin{array}{l}\mathrm{B} 5 \text { vitamins, } 2 \mathrm{mg} / \mathrm{L} 2,4-\mathrm{D}, 30 \\
\mathrm{mg} / \mathrm{L} \text { sorbitol and } 30 \mathrm{mg} / \mathrm{L} \\
\mathrm{mannitol}(\mathrm{NBO})\end{array}$ & $\begin{array}{l}\text { mg/L mannitol } \\
\text { (CO medium) }\end{array}$ \\
\hline 4. Duration & $4 \mathrm{hr}$ prior to bombardment & $4 \mathrm{hr}$ prior to bombardment \\
\hline $\begin{array}{l}\text { 5. Post-bombardment } \\
\text { medium }\end{array}$ & NB & CI medium \\
\hline 6. Duration & 7 days post-bombardment & 7 days post-bombardment \\
\hline 7. Subculture medium I & $\mathrm{NB}+50 \mathrm{mg} / \mathrm{L}$ hygromycin & $\mathrm{CI}+50 \mathrm{mg} / \mathrm{L}$ hygromycin \\
\hline 8. Subculture interval & 15 days (twice) & 15 days (twice) \\
\hline 9. Pre-regeneration medium & $\begin{array}{l}\mathrm{NB} \text { (without } 2,4-\mathrm{D})+5 \mathrm{mg} / \mathrm{L} \\
\mathrm{ABA}+2 \mathrm{mg} / \mathrm{L} \mathrm{BAP}+1 \mathrm{mg} / \mathrm{L} \\
\mathrm{NAA}+50 \mathrm{mg} / \mathrm{L} \text { hygromycin }\end{array}$ & $\begin{array}{l}\mathrm{CI}(\text { without } 2,4-\mathrm{D})+5 \mathrm{mg} / \mathrm{L} \\
\mathrm{ABA}+2 \mathrm{mg} / \mathrm{L} \mathrm{Kinetin}+1 \\
\mathrm{mg} / \mathrm{L} \mathrm{NAA}+50 \mathrm{mg} / \mathrm{L} \\
\text { hygromycin }\end{array}$ \\
\hline 10. Subculture Interval & 15 days & 15 days \\
\hline 11. Regeneration Media & $\begin{array}{l}\mathrm{NB}(\text { without } 2,4-\mathrm{D})+3 \mathrm{mg} / \mathrm{L} \\
\mathrm{BAP}+0.5 \mathrm{mg} / \mathrm{L} \mathrm{NAA}+50 \\
\mathrm{mg} / \mathrm{L} \text { hygromycin }\end{array}$ & $\begin{array}{l}\mathrm{MB}(\text { without } 2,4-\mathrm{D})+3 \mathrm{mg} / \mathrm{L} \\
\text { Kinetin }+0.5 \mathrm{mg} / \mathrm{L} \mathrm{NAA}+50 \\
\mathrm{mg} / \mathrm{L} \text { hygromycin }\end{array}$ \\
\hline 12. Subculture Interval & 15 days & 15 days \\
\hline 13. Plant Growth Media I & MS & MS \\
\hline 14. Subculture Interval & 15days & 15days \\
\hline
\end{tabular}

\section{Plasmid construct}

Plasmid pRQ6 (Figure 1), the vector used for the rice transformation experiments, given by $\mathrm{Dr}$. Rhonda $\mathrm{Qu}$ of the International Laboratory for Tropical Agriculture Biotechnology at the Scripps Research Institute (ILTAB/TSRI). This plasmid contains $\beta$-glucuronidase (GUS) gene under the control of cauliflower mosaic virus (CaMV) 35S promoter and the hygromycin phosphotransferase $(h p h)$ gene, encoding the enzyme hygromycin phosphotransferase which enhances resistance to hygromycin B under the control of CaMV $35 \mathrm{~S}$ promoter. 


\section{$2.08 \mathrm{~kb}$}

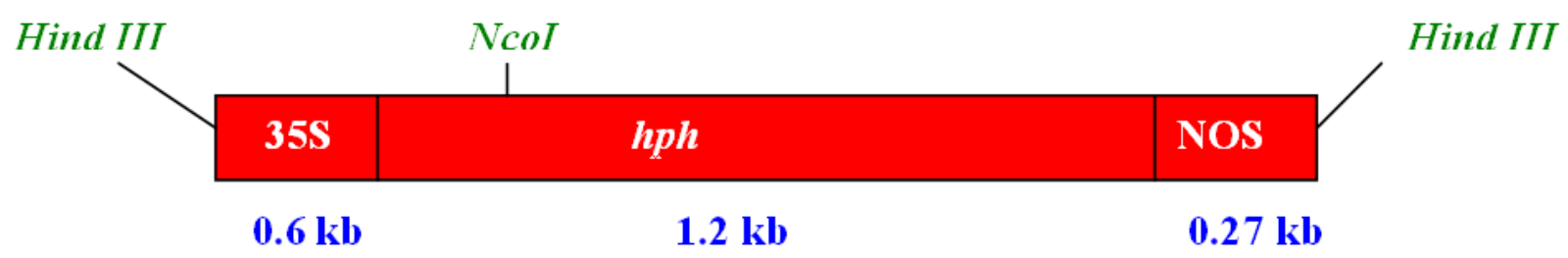

Figure 1. Restriction Enzyme Map of the $h p h$ and the gusA genes construct of pRQ6. Numerical values indicate approximate kilobase lengths.

\section{Preparation of DNA and particle delivery}

All DNA introductions into rice calli were done using a Biolistic PDS$1000 / \mathrm{He}$ Particle Delivery System (BioRad, USA). DNA preparation for bombardment was carried out by adding in order, $25 \mu \mathrm{l}$ of gold suspensions, $2.5 \mu \mathrm{g}$ DNA, $10 \mu \mathrm{l}$ spermidine, $50 \mu \mathrm{CaCl}_{2}$ and left at room temperature for $10 \mathrm{~min}$. A $7.5 \mu 1 \mathrm{pf}$ the particle DNA mixture was distributed on the microcarrier (Sivamani et al., 1996). Approximately, 50 pieces of four week old embryogenic callus were placed evenly on $\mathrm{CO}$ medium. The DNA delivery was used according to the manufacturer's instructions. All target tissues were placed at a distance of $5 \mathrm{~cm}$ from the stopping plate in the gene gun chamber at helium pressure of 1100 psi and were bombarded with single shots.

\section{Selection of transformants and recovery of hygromycin phosphotransferase (hpt) resistant rice plants}

Following bombardment, the callus cultures of Taipei 309 and MR 81 were subsequently then transferred to modified N6 and CI mediums, respectively. Hygromycin as a selection agent was chosen to select for callus that was stably transformed with $h p h$ gene. While callus growth still occurred at $30 \mathrm{mg} / \mathrm{L}$ hygromycin $\mathrm{B}$, callus development was effectively eliminated at $50 \mathrm{mg} / \mathrm{L}$. To minimize the possibility of escapes, a concentration of $50 \mathrm{mg} / \mathrm{L}$ was finally chosen for routine selection of transformants application (unpublished data). This concentration was also found to be efficient in preventing the growth of established non-transformed callus (data not shown). The time of the initial application of the selection agent ( 0 day or 7 days) did not influence the selection stringency during the callus regeneration phase. Therefore, day 7 was chosen by which time the expression of hygromycin should have been well established and first callus growth are imminent. After seven days post-bombardment, the callus were transferred with medium supplemented with $50 \mathrm{mg} / \mathrm{L}$ hygromycin B. Surviving white callus was further subcultured twice on a media of N6 or MS medium, with 50 $\mathrm{mg} / \mathrm{L}$ hygromycin B for another 14 days. After 4 weeks, shoots were transferred to MS hormone free medium with $50 \mathrm{mg} / \mathrm{L}$ hygromycin $\mathrm{B}$ to allow further development. Regenerated plantlets were transferred to soil in pots, and grown to maturity under glasshouse conditions. Two independent R1 plants which were progeny of plants M4 (cv MR 81) and R1 (cv Taipei 309) were examined. For each line, 40 seeds were randomly chosen from R0 plants and germinated on plant growth medium with $50 \mathrm{mg} / \mathrm{L}$ hygromycin $\mathrm{B}$ for three weeks.

\section{Histochemical GUS assay}

Transient gene expression experiments with rice callus for both varieties were done 2 days after bombardment in a GUS substrate mixture (Jefferson, 1987). The percentages of 
callus expressing GUS were recorded after being incubated in staining solution containing $1 \mathrm{mM}$ of 5-bromo-4-chloro-3indolyl glucuronide (X-Gluc) (Research Organics, Cleveland, Ohio, USA) in $50 \mathrm{mM}$ phosphate buffer, $\mathrm{pH} 7.0$ at $37^{\circ} \mathrm{C}$ overnight. The same procedure was used to assay GUS expression in leaf pieces, whole plantlet and inflorescence of putatively transformed R0 and R1 plants. For the leaves, chlorophyll was extracted after staining by incubation in $70 \%$ ethanol. Two independent R1 lines which were the progeny of M4 (cv. MR 81) and T1 (cv. Taipei 309) were examined. For each line, five seeds were randomly chosen from one panicle of R0 plants. A total of 40 seeds were inoculated on plant growth media containing $50 \mathrm{mg} / \mathrm{L}$ hygromycin $\mathrm{B}$. Leaves and roots were excised from each plant and examined for the presence of GUS activity (blue sectors).

\section{PCR assay of the putative transgenic rice plants}

Polymerase chain reaction (PCR) assay was used to detect $h p h$ gene in the R0 and R1 plants. Total DNA from putatively regenerated $\mathrm{R} 0$ and $\mathrm{R} 1$ rice plants of MR 81 and Taipei 309 were analysed by PCR using the primers that were specific to the coding region of the $h p h$ gene. The complete PCR mixture contained about 100ng genomic DNA, $5 \mu 1$ of 10x Taq-polymerase buffer (Boehringer), $0.5 \mu 1$ of $\mathrm{dNTP}$ mixture (10mM concentration each), $0.5 \mu 1$ Taqpolymerase (2.5 units), $0.5 \mu \mathrm{l}$ of both primers $(10 \mu \mathrm{M}$ each) in a final volume of $50 \mu 1$. The PCR cycles (Perkin Elmer) were at $94^{\circ} \mathrm{C}$ for $3 \mathrm{~min}$ for one cycle, $95^{\circ} \mathrm{C}$ for $30 \mathrm{sec}, 55^{\circ} \mathrm{C}$ for $1 \mathrm{~min}$ for 30 cycles and $72^{\circ} \mathrm{C}$ for $7 \mathrm{~min}$ for one cycle. An aliquot of $10 \mu 1$ of each reaction was used for electrophoresis on a 1\% TAE agarose gel.

\section{DNA Isolation and Southern blot analysis}

Genomic DNA was extracted from leaves of rice plants based on Dellaporta et al. (1983) with modifications. About $5 \mu \mathrm{g}$ of genomic DNA from each sample, undigested or digested with restriction endonucleases (Hind III and $\mathrm{Ncol}$ ) was used for electrophoresis in $0.8 \%$ agarose gel. Southern blot transfer to Hybond- $\mathrm{N}^{+}$ nylon membrane was according to manufacturer's instructions (Amersham, Arlington Heights, USA). Protocols for fixation, prehybridization, hybridization and washing of the membrane was in accordance to manufacturer's instructions. The ${ }^{32} \mathrm{P}$-probe for Hybridization was prepared using a PCR product of the $h p h$ gene with the Prime it II random priming kit (Strangene, CA, USA) according to the procedure supplied by the manufacturer.

\section{Results \\ Histochemical analysis of the GUS gene driven by CaMV 35S promoter}

Forty-eight hours

after

bombardment, the embryogenic callus cultures produced detectable levels of GUS activity after bombardment of particles coated with pRQ6 plasmid containing the $\beta$-glucuronidase gene as determined by the appearance of the blue colourations following the addition of enzyme assay substrate, while being cultured in $50 \mathrm{mg} / \mathrm{L}$ hygromycin B. All transgenic plant samples expressed the GUS gene in the roots, shoot tissues and inflorescence (Figure 2A-E). GUS activity was also observed in the hygromycin-resistant seedlings of R1. GUS expression in different tissues of R1 plants are shown in Figure 2A-E. About $25 \%$ of the Taipei 309 exhibited GUS activity while $20 \%$ of the MR 81 exhibited GUS activity. Hygromycin resistant somatic embryos induced from the transformed callus cultures were found to be uniformly GUS positive by histochemical assay (Figure 2B). This was an indicative of the presence 
and expression of gus $A$ as a reporter gene as well as the selectable marker gene. Untransformed control callus remain yellowish white in the presence of the XGluc. All transgenic plant samples of R0 and R1 generation expressed the GUS gene in roots, shoots tissues and inflorescence. Multiple shoots and roots emerged from resistant callus on the regeneration medium with selection within 2-3 weeks.
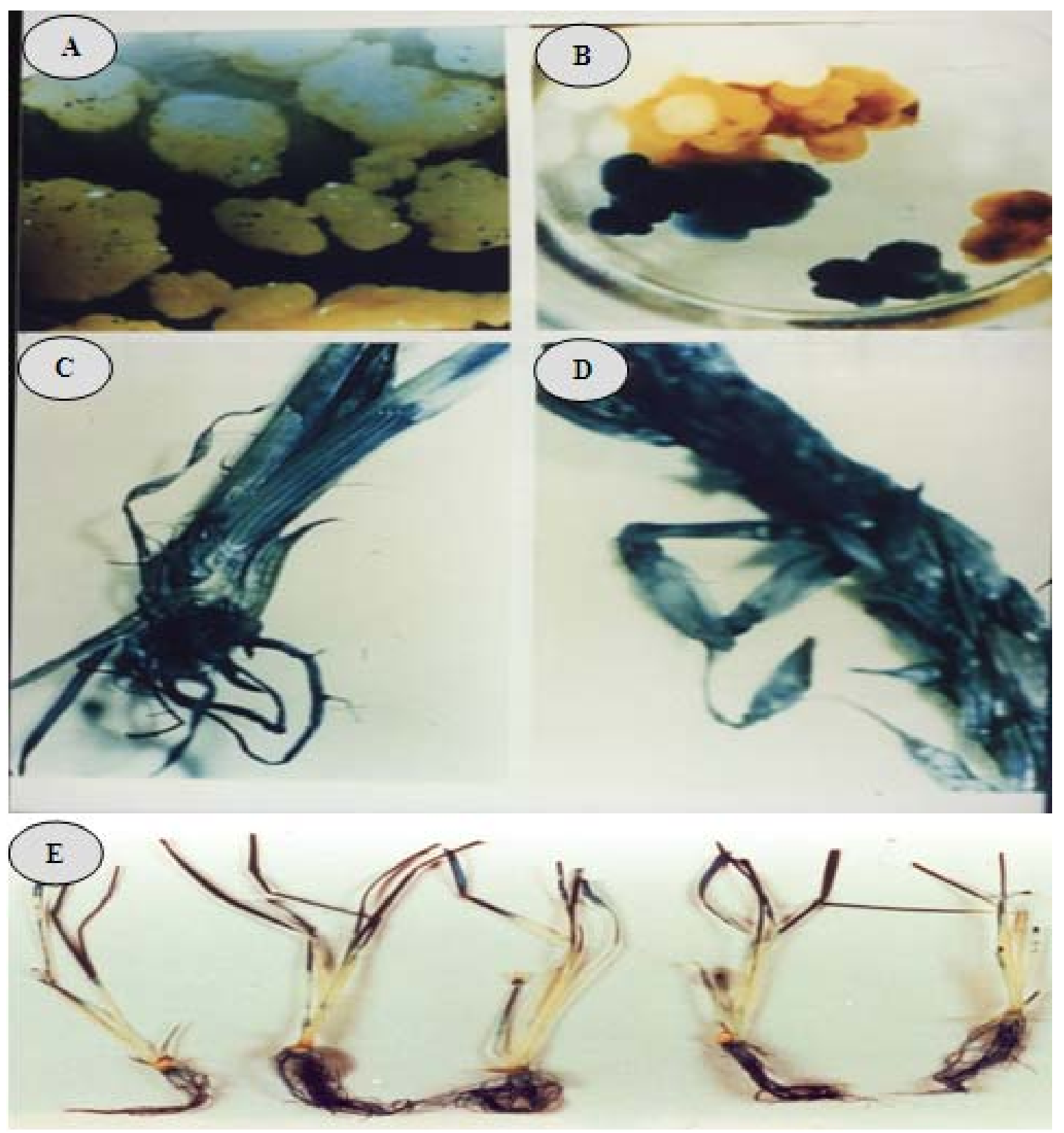

Figure 2. (A) Transient GUS expression in rice callus culture; (B) Hygromycin-resistant callus culture staining for GUS activity (blue) after 1 month of continuous culture onto hygromycin selection medium. The untransformed control callus does not express the GUS activity (white); (C, D): Hygromycin-resistant plants regenerated from transformed callus cultures, expressed GUS in the roots, leaves, stem and inflorescence; (E) GUS positive rice seedlings of MR 8. 

DNA transfer and selection of
transgenic rice plants

Callus bombarded with plasmid pQR6 grew well when placed on modified MS medium for the first 7 days. After being subjected to HPH selection for the following 3 weeks, most calli stopped growing, while a few putative transformants continued to grow (Figure 3B). In control treatment, the callus that was bombarded without plasmid DNA (i.e., no DNA) did not continue to grow under $\mathrm{HPH}$ selection. Since $50 \mathrm{mg} / \mathrm{L}$ of hygromycin $\mathrm{B}$ were effective in selecting the transformants (data not shown), we have used this concentration in the subsequent experiments. We have also observed that a selection pressure of $50 \mathrm{mg} / \mathrm{L}$ hygromycin B was strong enough to inhibit further development of the nonresistant somatic embryos at early stages of development and the same concentration could be used continuously at different phases of rice plant regeneration (Figure 3) and growth.

After being transferred to regeneration medium, HPH-resistant callus formed morphological structures resembling coleoptiles or shoots within 3 weeks. These structures developed into plantlets (Figure 3) when transferred to MS medium lacking plant growth regulators. After 5 weeks in the MS medium, these rice plantlets were readily transplanted into soil and grown in the greenhouse. Fortythree HPH-resistant callus from six separate experiments gave rise to at least 1 plantlets with some callus could produced more than 10 plantlets (Table 2). In five separate experiments, the measurement of morphological characters showed that the R0 transgenic plants of MR 81 (Table 3) and Taipei 309 had much lower average height and a higher number of tillers per plant. All transgenic R0 rice plants of Taipei 309 and MR 81 were set seeds upon self-pollination. The R0 plants of MR 81 and Taipei 309 and that of their progeny having the HPH gene germinated normally in the growth medium with $50 \mathrm{mg} / \mathrm{L}$ hygromycin B. All the 5 independent regenerated calli were positive for GUS and resistant on $50 \mathrm{mg} / \mathrm{L}$ hygromycin $\mathrm{B}$.

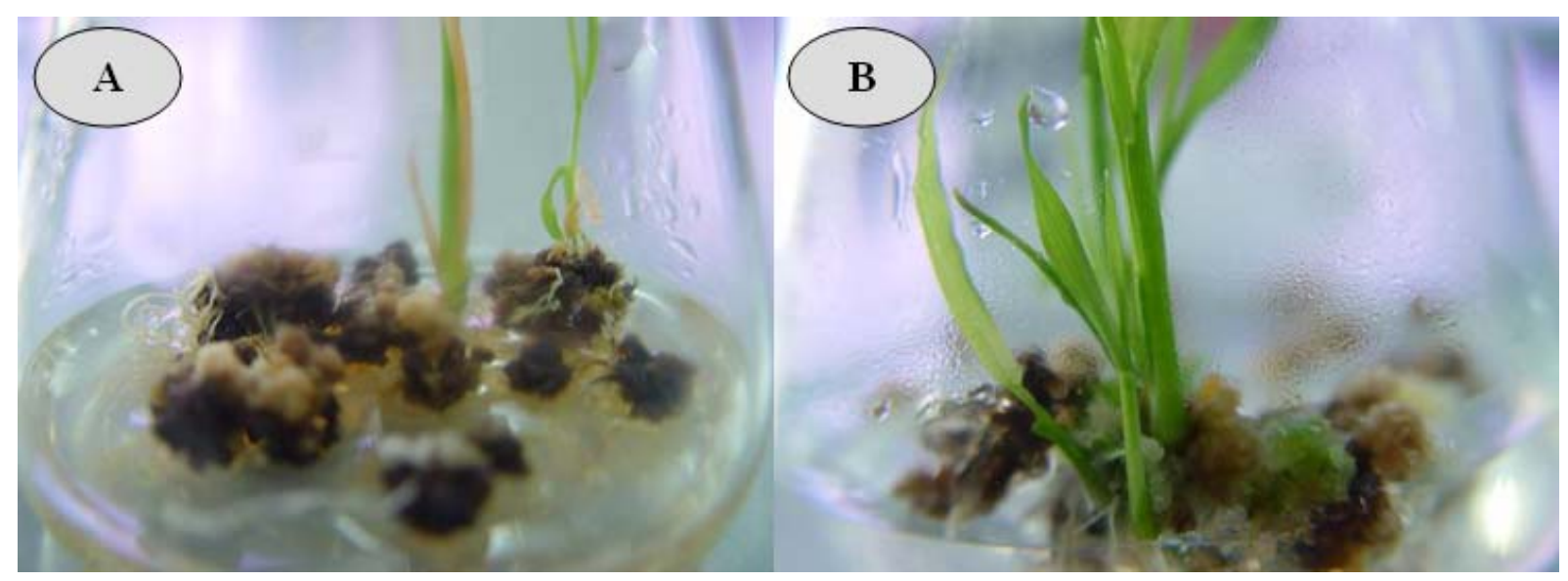

Figure 3. (A, B) Plant Regeneration of Taipei 309 and MR81 callus under selection medium containing $50 \mathrm{mg} / \mathrm{L}$ hygromycin $B$, respectively. 
Table 2. Regeneration of transgenic plantlets from HPH-resistant callus of MR 81.

\begin{tabular}{lll}
\hline Experiment number & $\begin{array}{l}\text { No of HPH-resistant callus } \\
\text { selected for regeneration }\end{array}$ & Regenerated rice plantlets \\
\hline A & 6 & 18 \\
B & 13 & 33 \\
C & 4 & 12 \\
D & 11 & 31 \\
E & 7 & 34 \\
f & 2 & 13 \\
\hline a Each HPH-resistant callus produced at least one plant. Some calluses were capable of generating of \\
10 plantlets.
\end{tabular}

Table 3. Plant height, tiller number, flat leaf length and length of second leaf of non-transformed (control) MR 81 and transformed MR 81 (7 weeks after transplanting).

\begin{tabular}{|c|c|c|c|c|c|}
\hline $\begin{array}{l}\text { Trough } \\
\text { number }\end{array}$ & Plant number* & $\begin{array}{l}\text { Plant height } \\
\text { (cm) }\end{array}$ & $\begin{array}{l}\text { Tiller } \\
\text { number }\end{array}$ & $\begin{array}{l}\text { Flat leaf } \\
\text { length } \\
\text { (cm) }\end{array}$ & $\begin{array}{l}\text { Second leaf } \\
\text { length } \\
\text { (cm) }\end{array}$ \\
\hline 1 & 5312 & 98 & 24 & 50 & 55 \\
\hline \multirow[t]{3}{*}{ Control } & Non-transformant & 117 & 17 & 56 & 63 \\
\hline & 5312 & 90 & 17 & 35 & 40 \\
\hline & 5291 & 85 & 17 & 29 & 36 \\
\hline \multirow[t]{2}{*}{ Seed } & Non-transformant & 123 & 17 & 60 & 70 \\
\hline & 5312 & 130 & 30 & 47 & 61 \\
\hline 2 & 5291 & 103 & 33 & 47 & 55 \\
\hline \multirow[t]{3}{*}{ Seed } & Non-transformant & 120 & 16 & 56 & 62 \\
\hline & 5264 & 98 & 12 & 43 & 53 \\
\hline & 5264 & 106 & 13 & 53 & 64 \\
\hline \multirow[t]{2}{*}{ Control } & Non-transformant & 115 & 14 & 51 & 69 \\
\hline & 5291 & 106 & 34 & 44 & 54 \\
\hline 3 & 5410 & 104 & 22 & 41 & 54 \\
\hline \multirow[t]{3}{*}{ Seed } & Non-transformant & 127 & 17 & 63 & 67 \\
\hline & 5312 & 100 & 14 & 37 & 54 \\
\hline & 5291 & 62 & 20 & 29 & 33 \\
\hline \multirow[t]{2}{*}{ Control } & Non-transformant & 116 & 21 & 52 & 65 \\
\hline & 5291 & 100 & 31 & 46 & 53 \\
\hline \multirow[t]{2}{*}{ Control } & Non-transformant & 120 & 19 & 57 & 67 \\
\hline & 5291 & 121 & 28 & 63 & 65 \\
\hline \multirow[t]{3}{*}{4} & 5351 & 121 & 28 & 63 & 65 \\
\hline & 5441 & 115 & 42 & 47 & 58 \\
\hline & 5351 & 111 & 39 & 48 & 63 \\
\hline Seed & Non-transformant & 123 & 33 & 57 & 69 \\
\hline 5 & 5410 & 108 & 33 & 48 & 51 \\
\hline \multirow[t]{3}{*}{ Seed } & Non-transformant & 127 & 25 & 56 & 67 \\
\hline & 5410 & 110 & 31 & 55 & 66 \\
\hline & 5410 & 109 & 33 & 51 & 54 \\
\hline \multirow[t]{2}{*}{ Control } & Non-transformant & 109 & 22 & 55 & 66 \\
\hline & 5431 & 96 & 18 & 44 & 56 \\
\hline
\end{tabular}

* Non-transformed MR81 are seed derived plants or control tissue culture plants regenerated by bombarding (without plasmid) or selection. 


\section{PCR analysis}

Amplification of the 900 base pair (bp) fragment could be identified from DNA of 5 putatively transformed (R0)
Taipei 309 and 12 of MR 81 plants indicating the presence of the $h p h$ gene in the R0 plants (Figure 4) and R1 plants.

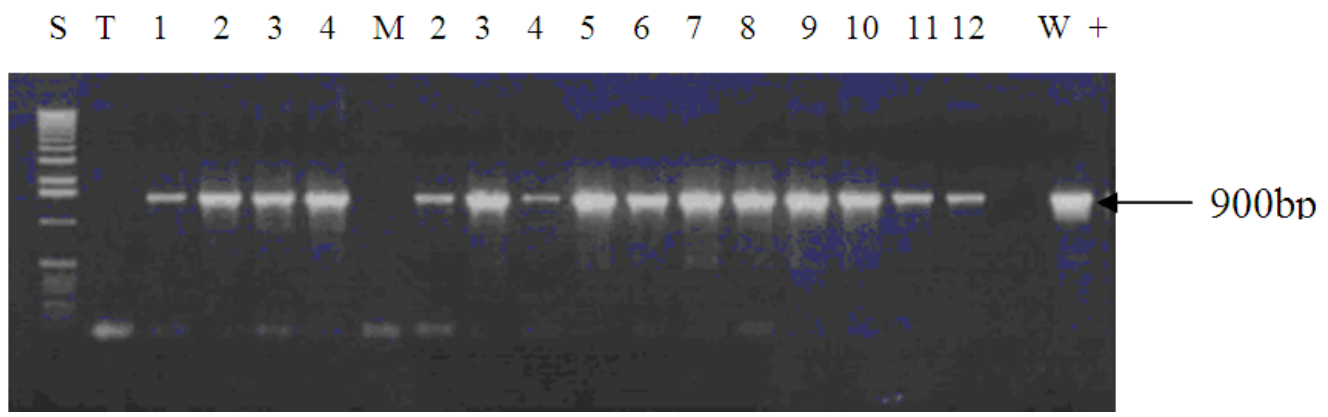

Figure 4. Agarose gel electrophoresis of PCR-amplified DNA from putative transgenic Ro rice plants. The results revealed the presence of the $900 \mathrm{bp}$ fragment of the $h p h$ gene in the rice genome in transformed plants of Taipei 309 (T onwards; Lanes 1-4), MR81 (M onwards; Lanes 2-12) and $\mathrm{W}^{+}$(positive control from the plasmid). The $h p h$ gene is not detected in the non-transformed plants (Lanes $\mathrm{T}$ and $\mathrm{M}$ ).

\section{Southern blot analysis of $\mathrm{RO}$ rice plants}

Southern blot analysis of DNA isolated from leaf blades of plants MR 81 and Taipei 309 regenerated from HPHresistant callus confirmed the presence of the HPH gene (Figure 5). As expected, neither undigested nor the digested genomic DNA from nontransformed plants hybridized with the $\mathrm{x}-\left[{ }^{32} \mathrm{P}\right]$-labeled $h p h$ gene probe. The nontransformed plant did not show any hybridization band. Integration of the HPH gene was illustrated by the formation of a smear in only the high molecular weight region (Figure 5) when undigested genomic DNA was hybridized with the $h p h$ probe. Six of the 12 plants illustrated in Figure 5 showed a hybridization signal in the $900 \mathrm{~kb}$ region corresponding to the intact $h p h$ gene coding sequence.

All the 5 plants of Taipei 309 in the Southern blot analysis showed similar pattern indicating that they were siblings (data not shown). The intact plasmid cassette is present as seen in the lane loaded with R1 genomic DNA digested with Hind III. Out of the 12 lines of MR 81 tested, 4 distinct lines were identified by Southern blot analysis (Figure 5a and 5b). Lines M4 and M9 have more copies of the $h p h$ gene than lines M3 and M 12 based on the intensity of the bands. Lines M3 and M12 have at least one insertion based on the visible bands. Lines M3 and M10 are siblings since they show a similar Southern pattern analysis.

\section{Phenotype of R0 plants and inheritance of the HPH gene}

The majority (>95\%) of hygromycin-resistant plants survived transfer to soil and flowered. As shown in Figure 6 most $(>85 \%)$ developed normally and set seeds. Sometimes R0 plants showed characteristics typical for tissue cultured-induced stress such as reduced stature. Nevertheless, the seeds of R0 plants are similar to seed-derived plants. Plants regenerated from HPH-resistant callus were designated as R0 plants. Seed of self-pollinated R0 plants gave rise to R1 plants. 


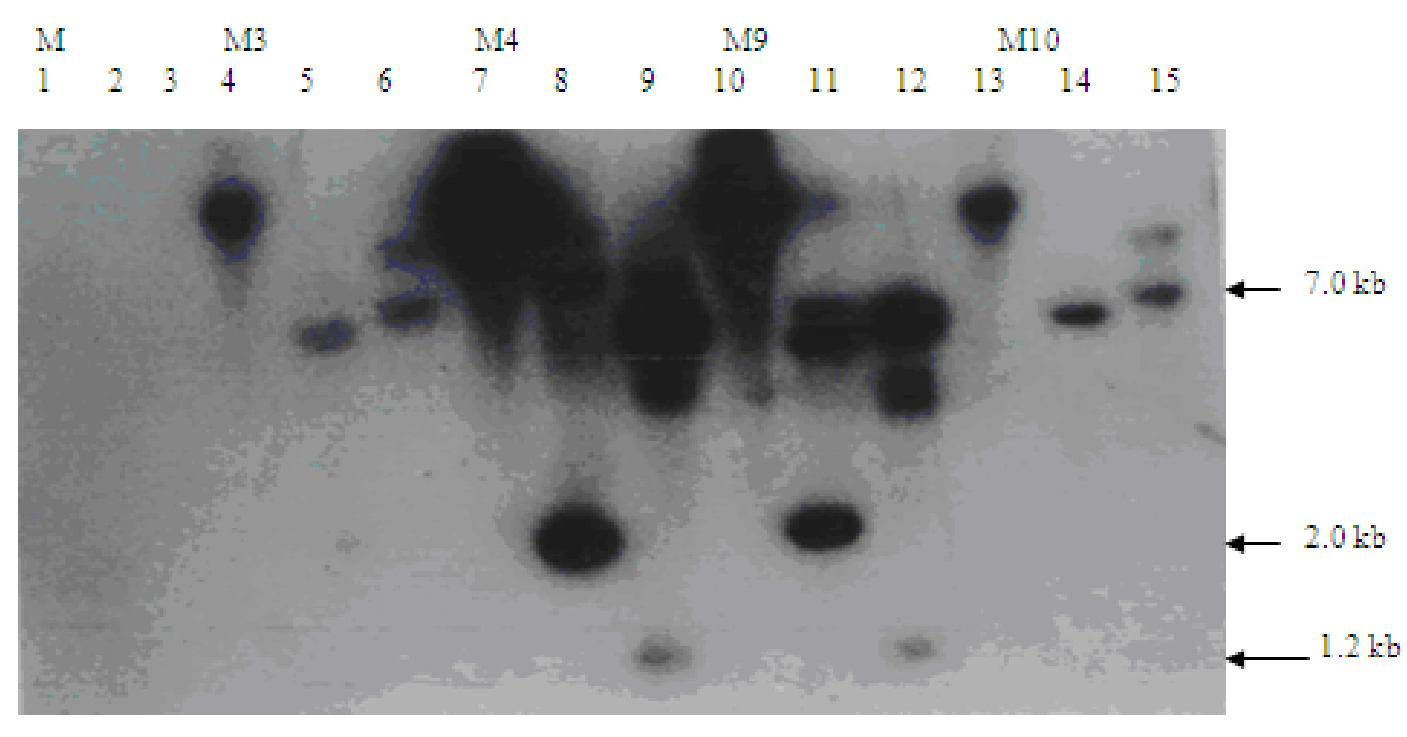

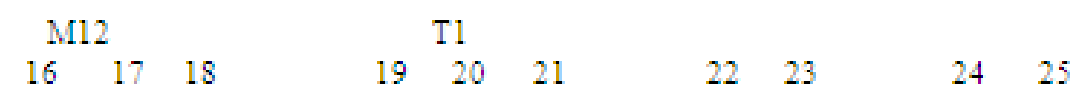

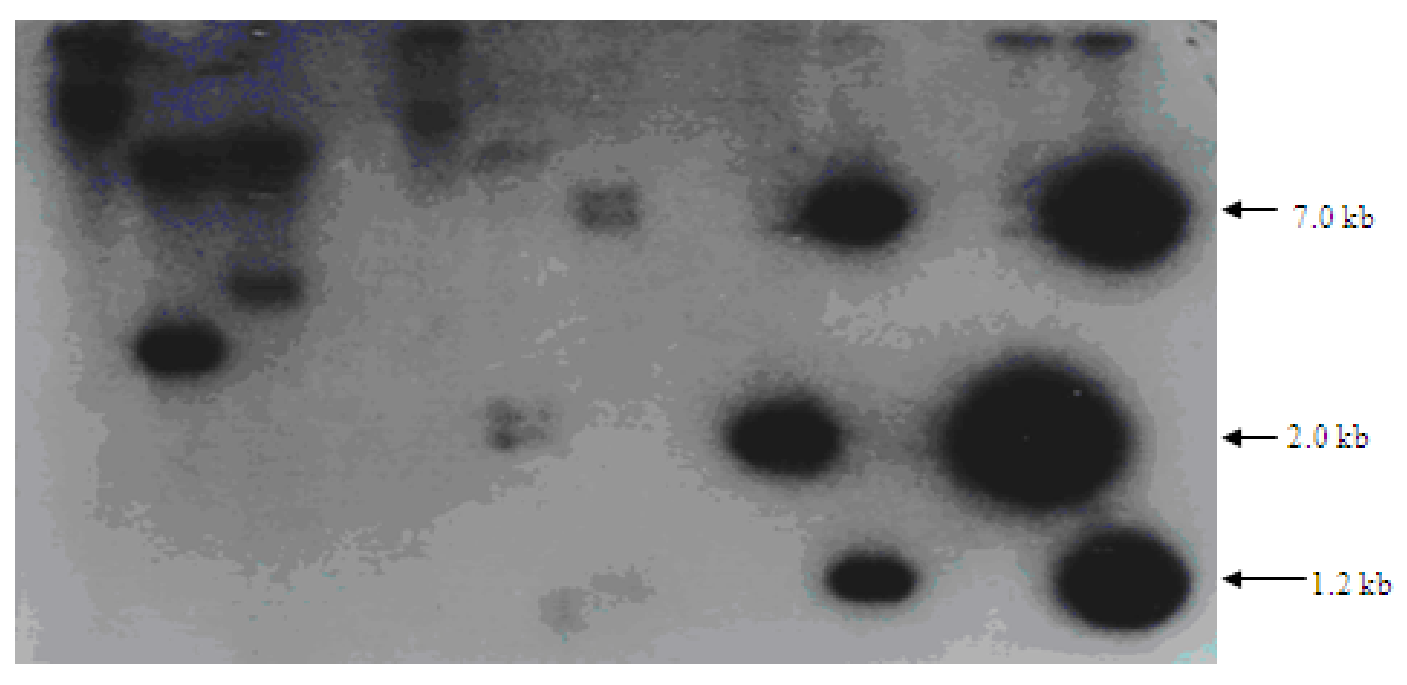

Figure 5. The Southern blot contains the genomic DNA samples of untransformed plants (MR 81) as control and 4 independent Ro transgenic lines (M 3, M 4, M 9 and M 12) of MR 81 and $T$ 1 of Taipei 309. $5 \mu \mathrm{g}$ of genomic DNA was used in all the lanes. Lanes 22 and 23: about 50pg of pRQ6, the plasmid DNA used in the transformation digested with Hind III and NCoI, respectively. Lanes 24 and 25: 100pg of pRQ6 digested with Hind III and NCoI, respectively. Lanes 1, 4,7,10,13,16 and 19: undigested genomic DNA of MR 81 and Taipei 309, respectively. Lanes 5, 8,11,14,17 and 20: digested with Hind III. Lanes 6, 9,12,15,18 and 21: digested with NCoI. The numbers on the side of the panel indicate the DNA size in $\mathrm{kb}$, based on the calibration with the $1 \mathrm{~kb}$ ladder (Gibco-BRL).

The Southern blot analysis conducted on progenies of MR 81 (M 4) and Taipei 309 $\mathrm{T} 1$ in the R1 generation confirmed the presence of the $h p h$ gene in the plants (Figure 7) that were also GUS positive. From the transformation experiments using calli derived from mature seeds of MR 81 and Taipei 309, four transformed lines of MR 81 and one line of Taipei 309 were chosen randomly for further assays. In all of these lines both GUS activity and hygromycin resistance has been confirmed by histochemical assay, PCR assay and Southern blot analysis. 

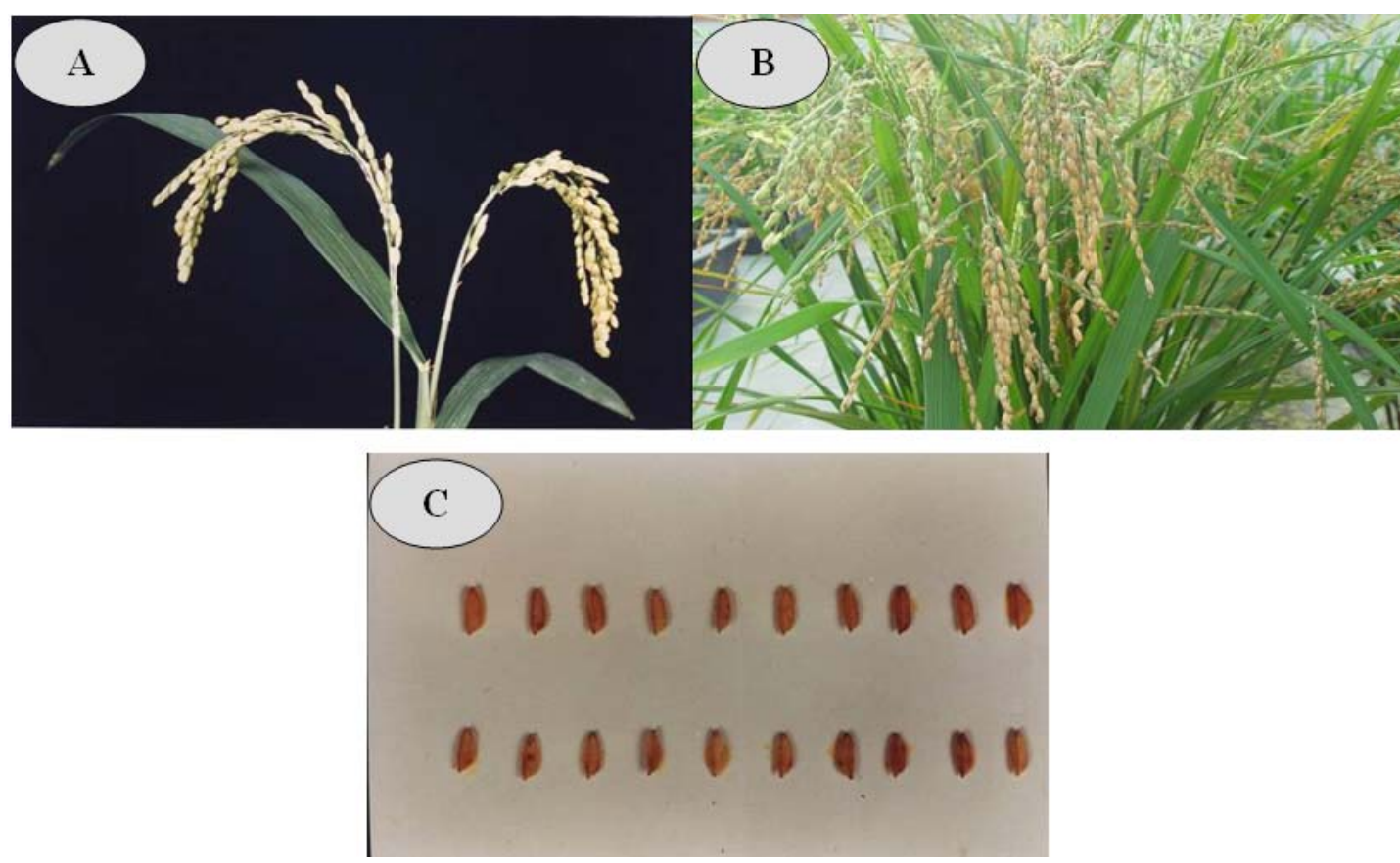

Figure 6. (A) Fertile transgenic R1 plants of Taipei 309; (B) Fertile transgenic R1 plants of MR 81; 7 (C) Seeds collected from transformed R1 plants of MR 81 are similar to the seeds of non-transformed plants grown under glasshouse conditions.

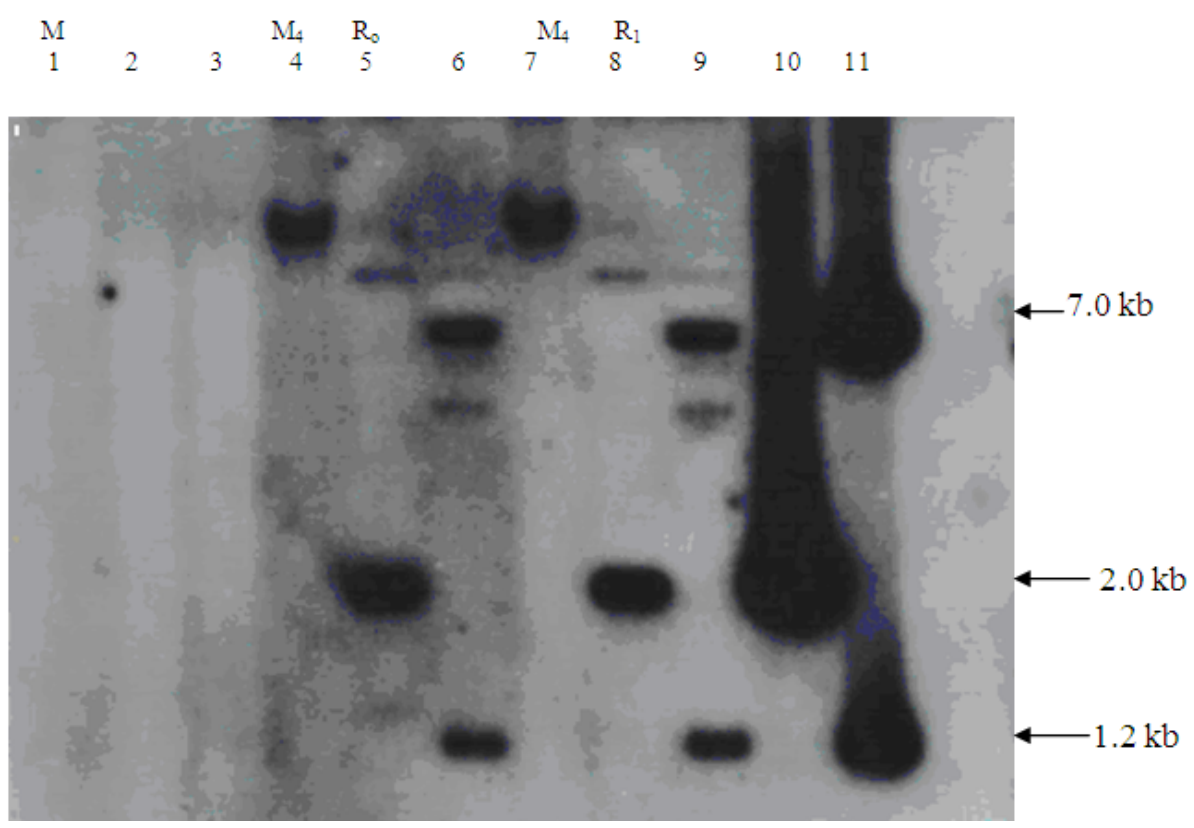

Figure 7. Southern bot analysis of R1 plants. The Southern blot contains the genomic DNA samples of untransformed plants of the MR81 (M) and Taipei 309 (T) as control, two independent R0 plants (M4 and T1). Lanes 10 and 11/11 and 12: about 50pg of pRQ6, digested with Hind III and NCoI, respectively. Lanes 1,4,7: undigested genomic DNA of M4/T1. Lanes 2, 5 and 8: digested with Hind III. Lanes 3, 6 and 9 digested with $\mathrm{NCoI}$. 
All plants were fertile, with more than $85 \%$ fertility in the panicles of all lines and are phenotypically normal. Both the $h p h$ and gusA genes were transmitted to the progeny as confirmed by histochemical assay, PCR assay and Southern blot analysis. Thus, the hph gene has proven to be a useful selectable and screenable marker for the transformation of MR 81 rice plants.

\section{Discussion}

Rice embryogenic callus is an effective starting material as explants, the choice of a biolistic process (also known as the particle gun bombardment) based system brought with it a number of both expected and fortuitous advantages. Brisibie et al. (2000) reported that wheat transformation using callus explant is profound importance in obtaining high percentage of tissues with transient and stable GUS activity. Proliferation of transformed cells and selection of transformed sectors is an important event since the transformed cells are at a disadvantage in terms of their retarded cell growth and multiplication in comparison to non-transformed ones (Visarada and Sarma, 2004). By utilising a somatic embryogenesis-based system of rice plants MR 81 and Taipei 309, we have reduced the probability production of transgenic chimera.

Competence was also assured by having an established totipotency while $\beta$ glucuronidase (gusA) gene immediately confirmed that these calluses were also competent for transformation. High frequencies of transient GUS expression, $25 \%$ to $30 \%$ range which are routinely obtained. The GUS reporter gene used to obtain data for the transient expression in these experiments, was found to be a reliable indicator for subsequent stable transgenic callus production. The GUS gene linked to the hygromycin $(h p h)$ gene was convenient to follow and confirm transformation events. Also, other authors have demonstrated that the CaMv35S can confer GUS expression in seeds of transgenic rice plant providing a useful marker for detecting transmission of the transgene to the progeny of transgenic plants. The method of selecting transferred rice resistant to hygromycin B has been well-established (Li et al., 1993). The hygromycin caused yellowing, stunted growth and necrosis of the untransformed seedlings. Ortiz et al. (1996) working on wheat has also reported the efficiency of utilizing hygromycin resistance gene as a selectable marker for stable transformation.

In the present study, the $h p h$ gene was absent in control rice tissue but present in both transformed leaves of the primary regenerants of R0 plants of Taipei 309 and MR 81 (Figure 5). Data showed that these R0 plants not only harbour the $h p h$ gene but also express it. Hygromycin resistant plants exhibited normal growth and tillering. Conveniently, there are few escapes at the callus level apparently had an altered physiological state that was not conducive to subsequent rice regeneration. The results presented here clearly indicate that DNA uptake into callus mediated by the particle bombardment transformation system is a reliable and reproducible method for genetically engineering indica rice plants when combined with appropriate callus culture and $\mathrm{HPH}$ selection protocols. When the $h p h$ gene was used as a selectable marker with the use of hygromycin B as a selective agent was crucial for identifying the transformed cells and subsequently regenerating plants from the transformed callus. The transformation efficiency of our experiment depended on the consistent quality of the callus. In our laboratory, transformation efficiency is measured by the number of HPH- resistant callus per plate. An average frequency of seven $\mathrm{HPH}-$ resistant callus produced transgenic plants from per plate from 50 bombarded calli (Table 2). The optimum regeneration 
procedure was found to be appropriate for both the genotype tested.

$$
\text { Particle bombardment }
$$
transformation system of an organized and easily regenerable tissue such as embryogenic callus allowed us to generate transgenic rice plants. In rice, earlier reports (Sivamani et al., 1996; Chen et al., 1998; Srivastava and Ow, 2001; Visarada and Sarma, 2004; Grewal et al., 2006) have successfully used embryogenic callus as starting material for transformation particle bombardment. The method presented in this study requires a short tissue culture period under optimal conditions, and rooted transformed plants could be transferred to the greenhouse about four months after bombardment. In our transformation experiments, no phenotypic abnormalities or reduced fertility of the regenerated plants were observed using MR 81 and Taipei 309 callus. Fertile plants from transformation events has been reported for transgenic maize (GordonKamm et al., 1990), wheat (Vasil et al., 1992), and transgenic oat plants (Somers et al., 1992) were obtained from particle bombardment of callus cultured or embryogenic suspensions. We observed various integration patterns of the introduced $h p h$ gene (Figure 6). The presence of multiple bands with molecular weights higher than expected is an indication of multiple insertion events and rearrangements of the integrated gene, both of which have been commonly observed in transformed plant materials (GordonKamm et al., 1990; Srivastava and Ow, 2001). Transformation experiments using calli derived from mature seeds of MR 81 and Taipei 309 have yielded 4 transformed lines of MR 81 and I line of Taipei 309. In all of these transgenic lines, both GUS activity and hygromycin resistance has been confirmed by histochemical assay, PCR assay and Southern blot analysis. All the rice plants were fertile, with more than $85 \%$ fertility in the panicles of all lines and are phenotypically normal. Both the $h p h$ and gusA genes were transmitted to the progenies as confirmed by histochemical assay, PCR assay and Southern blot analysis. Thus, the $h p h$ and gusA genes have proven to be useful selectable and screenable markers for the transformation of MR 81 rice plants. The next goal will be to use this transformation methodology to produce value-added transgenic plants by transferring single or many transgenes into commercially important rice varieties.

\section{References}

Becker, D., R. Brettschneider and H. Lorz. 1994. Fertile transgenic wheat from microprojectile bombardment of scutelar tissue. Plant J. 5:299-307.

Bower, R. and R. G. Birch. 1992. Transgenic sugarcane plants via microprojectile bombardment. Plant J. 2:409-416.

Bregitzer, P. and D., Tonks. 2003. Inheritence and expression of transgenes in barley. Crop Sci. 43:412.

Brisbie, E. A., A., Gajdosova, A. Olesen, and S. B. Anderson. 2000. Cyto differentiation and transformation of embryogenic callus lines derived from anther culture of wheat. J. Exp. Bot. 51:187-196.

Chen L., S. Zhang, R. N. Beachy, C. M. Fauquet. 1998. A protocol for consistent, large-scale production of fertile transgenic rice plants. Plant Cell Rep. 18:25-31.

Christou, P., T. L. Ford and M. Kofron. 1991. Production of transgenic rice (Oryza sativa L.) plants from agronomically important indica and japonica varieties via electric discharge particle acceleration of exogenous DNA into immature zygotic embryos. Biotechnol. 9:957962.

Dellaporta, S. J., J. Wood and J. B. Hicks. 1983. A plant minipreparation: 
Version II. Plant Mol. Biol. Rep. 14:19-21.

Finer, J. J. and M. D. McMullen. 1990. Transformation of cotton via particle bombardment. Plant Cell Rep. 8:586589.

Gordon-Kamm, W. J., T. M. Spencer and M. L. Mangano 1990. Transformation of maize cells and regeneration of fertile transgenic plants. Plant Cell Rep. 2:603-618.

Grewal, D., R. Gill and S. S. Gosal. 2006. Genetic engineering of Oryza sativa by particle bombardment. Biol Plant. 50(2):311-314.

Jefferson, R. A. 1987. Assaying Chimeric Genes in Plants: The GUS gene fusion system. Plant Mol. Biol. Rep. 5:387-405.

Li, L., R. Qu, A. de Kochko, C. Fauquet and R. N. Beachy. 1993. An improved rice transformation system using the biolistic method. Plant Cell Rep. 10:401-405.

McCabe, M. S., F. Schepers, A. van der Arend, U. Mohapatra, A. M. M. de Laat, J. B. Power and M. R. Davey. 1999. Increased stable inheritance of herbicide resistance in transgenic lettuce carrying a petE promoter-bar gene compared with a CaMV 35S-bar gene. Theor. App. Gen. 99:587-592.

Murashige, T. and F. Skoog. 1962. A revised medium for rapid growth and bioassays with tobacco tissue cultures. Physiol. Plant. 15:473-497.

Ortiz, J. P. A, M. I. Reggiardo, R. A. Ravizzini, S. G. Altabe, G. D. L. Cervigni, M. A. Spitteler, M. M. Morata, F. E. Elias and R. H. Vallejos. 1996. Hygromycin resistance as an efficient selectable marker for wheat stable transformation. Plant Cell Rep. 15:877-881.
Sivamani, E., P. Shen, N. Opaika, R. N. Beachy and C. M. Fauquet. 1996. Selection of large quantities of embryogenic calli from indica rice seeds for production of fertile transgenic plants using the biolistic method. Plant Cell Rep. 15:322-327.

Somers, D. A., H. W. Rines, W. Gu, H. F. Kaeppler and W. R. Bushnell. 1992. Fertile, transgenic oat plants. Biotechnol.10:1589-1594.

Srivastava, V. and D. W. Ow. 2001. Biolistic mediated site-specific integration in rice. Mol. Breed. 8(4):345-349.

Valdez, M., J. L. Cabrera-Ponce, D. Sudhaker and L. Herrera-Estrella. 1998. Transgenic Central American, West African and Asian elite rice varieties resulting from particle bombardment of foreign DNA into mature seed-derived explants utilizing three different bombardment devices. Ann. Bot. 82:795-801.

Vasil, V., A., Castillo, M., Fromm and I., Vasil. 1992. Herbicide resistant fertile transgenic wheat plants obtained by micro-projectile bombardment of regenerable embryogenic callus. Biotechnol. 10:667-674.

Visarada, K. B. R. S. and N. P. Sarma. 2004. Transformation of indica rice through particle bombardment: factors influencing transient expression and selection. Biol. Plant. 48(1):25-31.

Weeks, J. T., O. D. Anderson and A. E. Blechl. 1993. Rapid production of multiple independent lines of fertile transgenic wheat (Triticum aestivum L.). Plant Physiol. 102:1077-1084. 